\title{
Diferenças da escrita idiomática para harpa de pedais em relação àquela para pianoforte na segunda metade do século XVIII e início do XIX, exemplificadas através de obras de Jan Ladislav Dussek
}

Felipe Faglioni (Universidade de São Paulo, São Paulo, São Paulo, Brasil) felipemus847@gmail.com

\begin{abstract}
Resumo: O presente artigo trata da escrita idiomática para harpa de pedais na segunda metade do século XVIII e início do XIX e de aspectos que a distinguem daquela associada ao pianoforte durante o mesmo período. A fim de exemplificar diferenças existentes na música idiomaticamente bem escrita para os dois instrumentos, enfatizando questões envolvendo as características da harpa, o texto faz uma análise de trechos de composições e transcrições realizadas por Jan Ladislav Dussek (1760-1812), importante compositor e intérprete da época, cujo conhecimento dos citados instrumentos e de suas peculiaridades faz de sua música para harpa de pedais e para pianoforte um importante referencial dentre o assunto proposto.
\end{abstract}

Palavras-chave: Harpa de pedais; Escrita idiomática; Jan Ladislav Dussek; Pianoforte.

\section{Differences between the idiomatic writing for the pedal harp and for the pianoforte at the end of the 18th century and the beginning of the 19th century, exemplified by works by Jan Ladislav Dussek}

\begin{abstract}
This paper deals with the idiomatic writing for the pedal harp in the second half of the 18th century and the beginning of the 19th century, and with aspects that distinguish it from those associated with the pianoforte during the same period. In order to exemplify the existing differences between the music idiomatically well written for one instrument and the other, laying emphasis on questions involving the characteristics of the harp, the text analyses parts of compositions and transcriptions made by Jan Ladislav Dussek (1760-1812), an important composer and performer of the period, whose knowledge of the said instruments and their peculiarities makes his music for the pedal harp and for the pianoforte an important reference among the proposed subject.
\end{abstract}

Keywords: Pedal harp; Idiomatic writing; Jan Ladislav Dussek; Pianoforte.

\section{Introdução}

A escrita idiomática ${ }^{1}$ para harpa de pedais no século XVIII está muito relacionada àquela dos instrumentos de teclado, graças a certas semelhanças por eles compartilhadas. Tanto o instrumento de cordas dedilhadas quanto os munidos de teclas caracterizam-se como harmônicos, capazes, portanto, de produzir diversos sons simultaneamente e realizar acordes, melodias acompanhadas etc. O último quarto do século XVIII, período no qual a harpa de pedais conta com um repertório próprio e idiomático que continuará a crescer nos anos seguintes (BARTHEL, 2005, p. 127; RENSCH, 2017, p. 142), é também a época na qual o pianoforte torna-se cada vez mais popular, já anunciando a superação do cravo como o instrumento de teclado preferido de grande parte dos compositores do período (COLE, 2001; PARKER, 2005), apresentando também um repertório em constante expansão. Nesse contexto, em uma época na qual tanto a harpa quanto o pianoforte são instrumentos de destaque nos meios musicais nos quais se inserem, as já citadas semelhanças entre suas respectivas escritas fazem com que, não raramente, haja comparações entre seus repertórios. Dessa forma, as associações entre a música para harpa e para pianoforte da época são quase que inevitáveis, pois ambos os instrumentos parecem fundamentar seus respectivos "idiomas" nas mesmas bases. 
No entanto, apesar de similares, as escritas idiomáticas dos dois instrumentos nunca foram idênticas e sua análise mostra que as mesmas apresentam diferenças significativas, mesmo que às vezes não tão claras à primeira vista (VERNILLAT, 1969, p. 163).

Através do conhecimento de seu repertório setecentista é possível identificar peculiaridades da escrita para harpa de pedais e perceber que sua música apresenta elementos que normalmente são escritos idiomaticamente, de forma a privilegiar sua técnica e sua boa sonoridade. Logicamente, com o pianoforte isso não é diferente. Apesar de sua música conter basicamente os mesmos elementos presentes nas composições para harpa, elementos esses que fazem parte do estilo e da linguagem da música então em voga, eles são aqui utilizados em favorecimento da técnica e das possibilidades pianísticas.

Ambos os instrumentos eram muito diferentes entre si e apresentavam características e possibilidades distintas. Portanto, mesmo que sua música tenha sido escrita sob um mesmo estilo e possua uma linguagem similar, ela também apresenta diferenças relacionadas às particularidades de cada meio para o qual foi composta. Cabia aos compositores conhecer essas particularidades e saber utilizar-se delas da melhor maneira possível.

Quanto aos aspectos harmônicos, por exemplo, a música para harpa e a para pianoforte do citado período apresenta diferenças significativas que interferem diretamente na qualidade e no interesse musicais de seus respectivos repertórios. Inegavelmente, sob esses aspectos, a maioria das composições para harpa de pedais de ação-simples (o tipo de harpa de pedais utilizado ao longo de todo o século XVIII e começo do XIX) ${ }^{2}$ pode ser, de certa forma, obscurecida pela música para pianoforte da época.

Na segunda metade do século XVIII, grande é o número de publicações de partituras contendo a informação de que sua música poderia ser executada por ambos os instrumentos. Muitas composições para harpa têm em seus frontispícios a indicação "para harpa ou pianoforte”. Não obstante, o inverso, ainda que existente, é mais raro de ser encontrado.

De fato, devido às limitações da harpa de ação-simples em relação às suas possibilidades modulatórias e cromáticas ${ }^{3}$, é possível dizer que praticamente todo o seu repertório poderia ser executado ao pianoforte, mas nem toda peça para pianoforte seria possível na harpa. O primeiro, por suas características naturais, mostrava-se um instrumento mais versátil e, ao menos harmonicamente, dotado de maiores possibilidades.

As limitações harmônicas da harpa de pedais de ação-simples foram algumas das principais incitadoras da criação do mecanismo de ação-dupla, que viria a resolvê-las em grande parte (ÉRARD, 1821, p. 6-7; FÉTIS, 1831, p. 14-15; GRANGIER, 1924, p. 2). No entanto, durante o século XVIII os músicos tiveram de lidar com as possibilidades do tipo de harpa da qual dispunham.

$\mathrm{Na}$ intenção de se comparar diretamente a linguagem e escrita para os dois instrumentos, é interessante que sejam analisadas peças de compositores que tenham deixado uma obra significativa para harpa, para pianoforte ou para ambos. Além disso, obras nas quais os dois instrumentos são abordados de forma próxima (como duos, por exemplo) são excelentes maneiras de se observarem suas diferenças de escrita e compreender a individualidade com a qual um compositor aborda cada instrumento.

A partir desse ponto de vista, talvez nenhuma obra seja mais relevante do que aquela escrita por Jan Ladislav Dussek (1760-1812).

\section{Dussek e a harpa de pedais}

Dussek, compositor nascido na Boêmia, foi um dos mais importantes pianistas virtuosos da Europa na segunda metade do século XVIII e deixou ao pianoforte uma obra 
extremamente significativa (CRAW, 2001), na qual é possível perceber o alto grau de conhecimento da técnica e da escrita idiomática pianísticas que o músico possuía.

Apesar de grande parte de sua música ser dedicada ao pianoforte (BARTHEL, 2005, p. 176; CRAW, 2001), Dussek escreveu também uma variedade de obras para harpa de pedais de ação-simples e suas peças para o instrumento podem ser consideradas como algumas das mais importantes do período.

É curioso o fato de que em um meio onde a maior parte da música para o instrumento foi escrita por harpistas, as composições de Dussek, que não tocava harpa, ocupem posição de destaque. Algumas de suas obras fazem parte do repertório de harpistas ainda hoje (GRIFFITHS, 1968, p. 419) e são excelentes exemplos da escrita idiomática harpística do século XVIII. Mesmo tendo composto parte de sua música para harpa no início do século XIX, Dussek preservou nela o mesmo tipo de escrita para o instrumento do período anterior.

O compositor parece sempre ter tido um contato direto com harpa, uma vez que sua mãe e sua irmã eram harpistas (BARTHEL, 2005, p. 175; RENSCH, 2017, p. 141). Sua esposa, Sophia Corri (1775-1831), foi também uma importante intérprete do instrumento de pedais e é muito provável que sua relação com Dussek tenha contribuído significativamente na produção harpística do compositor.

Mesmo não tocando harpa, Dussek conhecia muito bem o instrumento e sua linguagem. Isso transparece em sua música, que apresenta muitas das características da escrita idiomática para harpa comumente encontradas nas composições de harpistas.

Somado à qualidade musical proveniente de um bom compositor, fortemente conhecedor de seu métier (o próprio Joseph Haydn declarou considerá-lo um músico de talento admirável [CRAW, 2001]), o alto conhecimento da harpa mostrado por Dussek explica o local de importância ocupado por suas composições em meio ao repertório da mesma.

A produção de Dussek voltada para a harpa consta de várias obras, entre as quais concertos para harpa e orquestra, sonatas para harpa solo ou acompanhada de outros instrumentos e duos para harpa e pianoforte. Dussek mostrou-se um grande conhecedor de ambos os instrumentos, e justamente por isso sua música é uma boa fonte na análise da escrita idiomática que cada um deles apresentava na segunda metade do século XVIII e início do XIX.

As análises a seguir não têm a pretensão de sistematizar todas as diferenças entre a escrita idiomática para esses instrumentos, uma vez que elas podem se apresentar de muitas formas diferentes. Portanto, mostrar-se-ão aqui alguns trechos de obras de Dussek nos quais algumas das peculiaridades da escrita idiomática para harpa e para pianoforte são exemplificadas, a fim de que se possa comparar a maneira como um mesmo compositor pensava a música para dois instrumentos diferentes.

\section{Dussek e transcrições de concertos}

O Concerto para harpa e orquestra, Opus 15, composto por Dussek em Londres, em 1789, mostra interessantes exemplos do uso do idiomatismo instrumental. A obra foi originalmente escrita para harpa solista, mas também poderia ser executada ao pianoforte, como era na época grande parte desse gênero de composição. Esse procedimento não era incomum naquele período. Exemplos similares podem ser também encontrados em música de outros gêneros (como sonatas para instrumento solo) e de outros compositores.

Em uma de suas publicações, a partitura do solista, editada para o pianoforte, apresenta no primeiro movimento da obra trechos nos quais são sugeridas partes diferentes 
das originalmente escritas para harpa ${ }^{4}$. Nota-se nesses pequenos trechos alternativos um cuidado especial da parte de Dussek ao transcrever o concerto para o pianoforte. O instrumento apresentava condições de executar a peça quase que exatamente da forma como havia sido escrita originalmente para harpa. No entanto, o compositor reescreve parte da música, de forma a valorizar o instrumento de teclas e suas possibilidades.

Nos exemplos a seguir, a parte escrita para harpa (provavelmente a primeira a ser composta) aparece acima da parte de pianoforte, numa fonte menor.

Nas Figuras 1 e 2 veem-se dois momentos em que o compositor, na parte para pianoforte, faz uso contínuo de cromatismos. Na harpa, seria praticamente impossível executar os mesmos trechos no andamento exigido pelo movimento (Allegro):

Figura 1: Uso de cromatismos (segundo compasso do pentagrama inferior) na transcrição da parte de harpa (pentagrama superior) para pianoforte, feita por Dussek

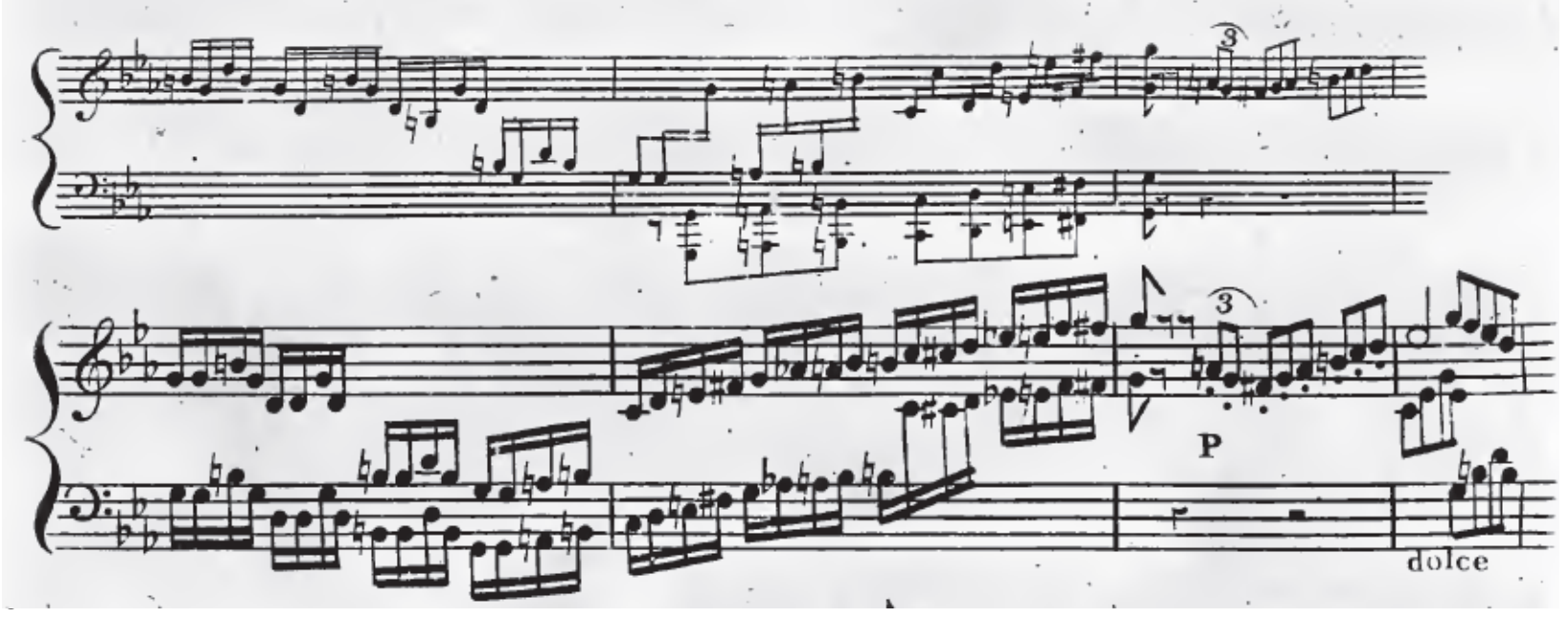

Figura 2: Figuras cromáticas (segundo compasso do pentagrama inferior) substituem as partes originalmente escritas para harpa

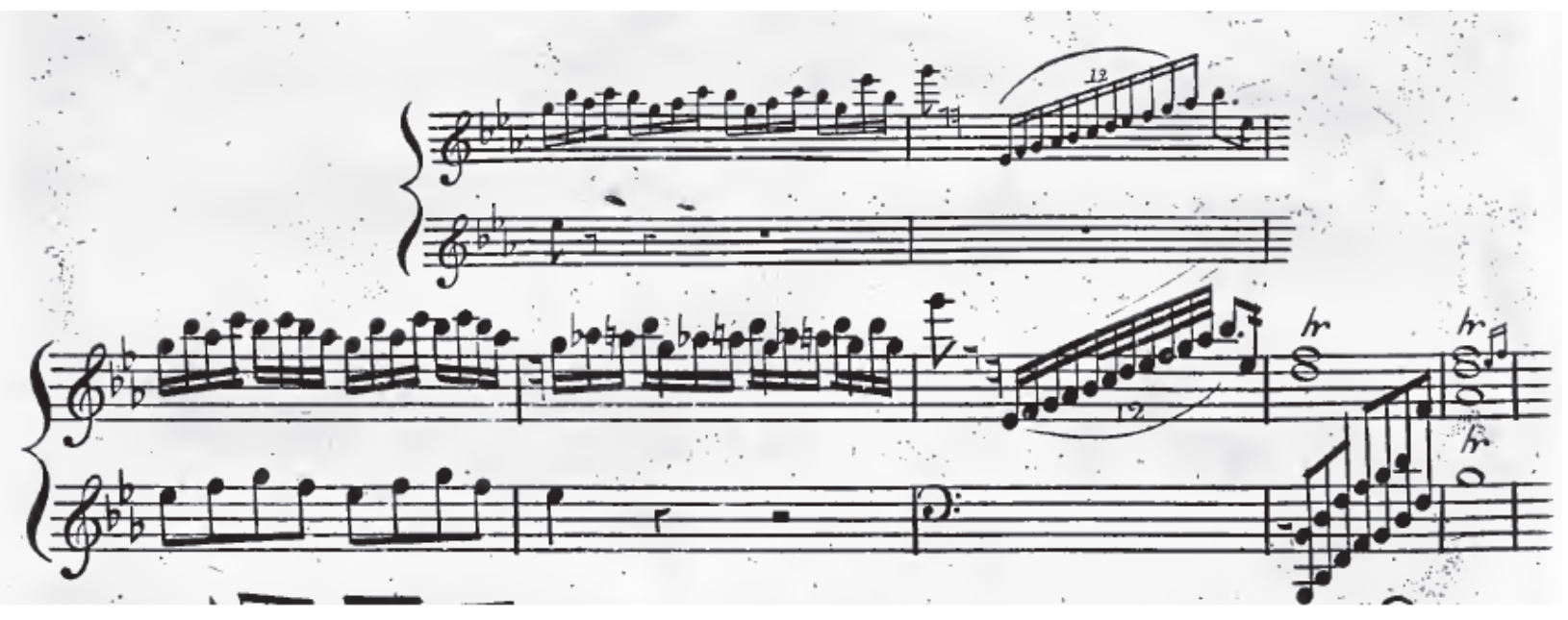

A harpa, sendo essencialmente um instrumento diatônico, sempre apresentou dificuldades na execução de cromatismos, que são possíveis somente através da ação dos pedais. Consequentemente, figuras cromáticas rápidas só podem ser realizadas no instrumento a muito custo e com resultado sonoro insatisfatório. Dussek aproveita-se da facilidade com a qual o pianoforte poderia realizar essas mesmas figurações e as utiliza muito provavelmente na intenção de trazer maior interesse e variedade aos trechos. 
Em outros momentos, Dussek escreve para o pianoforte figurações que, apesar de não impossíveis para a harpa, poderiam não soar muito claras quando executadas pela mesma.

Figura 3: Uso da região grave do pianoforte (compassos 2 e 3 do pentagrama inferior) em sua transcrição da parte de harpa (pentagrama superior)

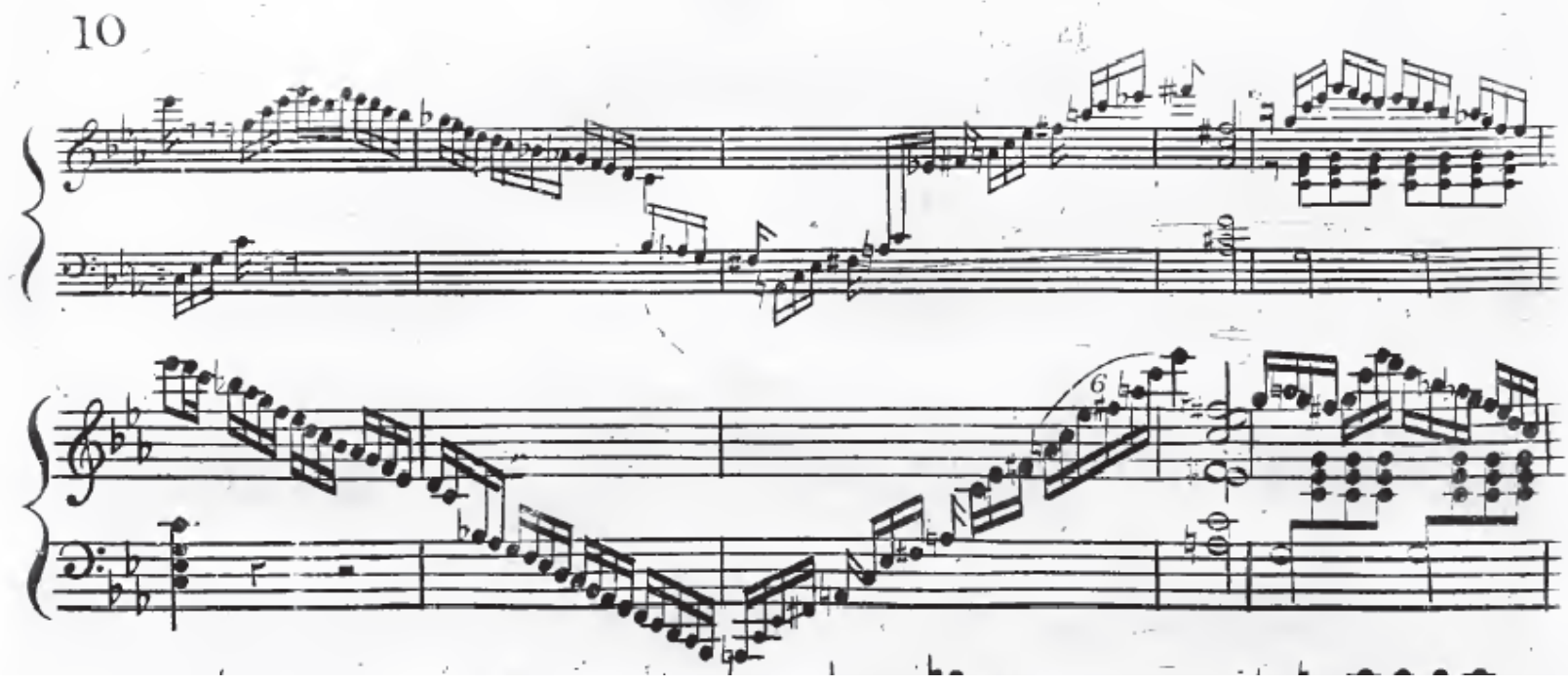

Na Figura 3, a parte de pianoforte é composta por uma longa escala diatônica descendente que culmina numa série de arpejos ascendentes de um acorde de sétima diminuta. A parte de harpa também apresenta escalas descendentes e os mesmos tipos de arpejo. No entanto, suas escalas permanecem numa região mais aguda do instrumento. Dussek com certeza sabia que escalas executadas rapidamente na harpa não soariam satisfatórias quando aplicadas em suas regiões mais graves. $\mathrm{O}$ fato de as cordas do instrumento permanecerem vibrando por certo tempo após serem tocadas, sem poderem ser completamente abafadas, torna as escalas no extremo grave do instrumento pouco claras e articuladas, ainda mais se tocadas muito rapidamente. Já no pianoforte, as escalas em sua região grave poderiam soar muito bem articuladas e completamente inteligíveis e, logo, Dussek as utiliza dessa forma.

Um exemplo parecido encontra-se na Figura 4. A parte de pianoforte (vista nos sistemas de baixo) é composta de grupos de semicolcheias tocadas em oitavas pelas duas mãos do pianista, sendo que a primeira de cada grupo é repetida rapidamente. Ainda que não impossíveis na harpa, essas figurações, que ao pianoforte soam virtuosas e com excelente sonoridade, não teriam bom resultado sonoro e apresentariam muito mais dificuldade de execução ao harpista. Os arpejos simples pelos quais Dussek originalmente optou na parte de harpa (os dois sistemas superiores) são realmente muito mais satisfatórios no instrumento: 
Figura 4: Partes de pianoforte (pentagramas inferiores) transcritas das partes originais para harpa (pentagramas superiores)
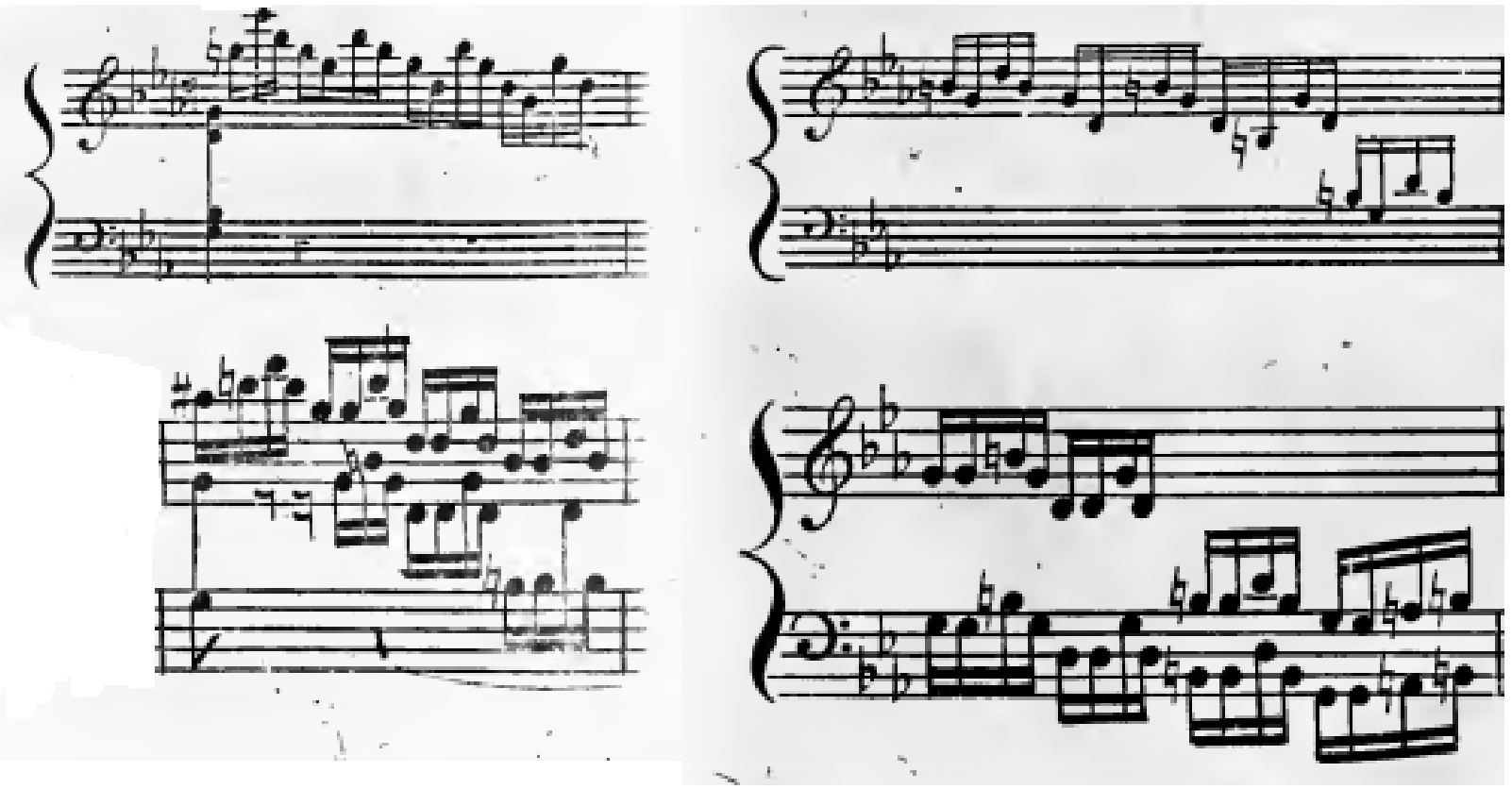

No exemplo a seguir (Figura 5) percebe-se que o compositor opta por escrever o trecho para pianoforte uma oitava abaixo da parte de harpa. Os pianofortes da época não possuíam a mesma extensão dos pianos modernos, em muitos casos não ultrapassando o limite de pouco mais de cinco oitavas (COLE, 2001). De fato, nessa edição da obra, as partes de pianoforte não vão além da nota Fá 5, enquanto que as de harpa atingem o Si Bemol 5. Dussek, portanto, respeita a extensão do instrumento de teclas, transcrevendo o trecho em uma região mais grave. A parte original para harpa é concebida em uma região mais aguda, que confere ao trecho uma sonoridade mais brilhante proveniente do uso desse registro do instrumento.

Figura 5: Parte de pianoforte transcrita uma oitava abaixo da original para harpa (a partir do segundo compasso)

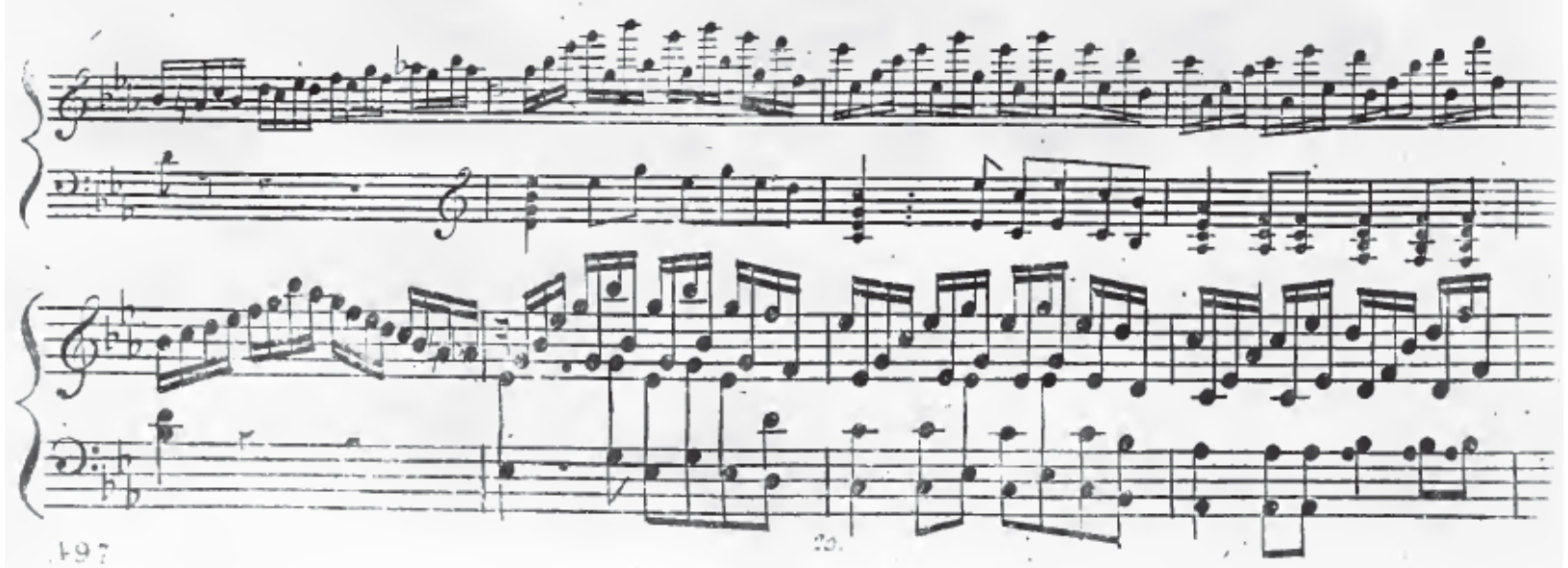

Outra obra interessante na comparação da escrita para harpa e para pianoforte de Dussek é na verdade uma transcrição de uma peça de outro compositor. Na primeira página de sua edição, de 1790, lê-se: "Favorito concerto para harpa de Krumpholtz adaptado para o cravo ou pianoforte por J. L. Dussek, como executado sob grande aplauso por ele e por Muzio Clementi” ${ }^{5}$. A peça é uma transcrição para pianoforte do Concerto para harpa em Fá maior, Opus 9, de J. B. Krumpholtz ${ }^{6}$ (1742?-1790). As informações do frontispício da edição 
ressaltam a ideia da popularidade desfrutada pela peça, que provavelmente por isso teria recebido a tal transcrição e sido executada por reconhecidos pianistas da época.

Realizando a transcrição de uma obra de outro compositor, Dussek provavelmente não teria a mesma liberdade que ao transcrever uma peça de sua própria autoria. De qualquer modo, suas alterações feitas na partitura original de Krumpholtz são de tipo muito semelhante às realizadas na transcrição para pianoforte de seu concerto para harpa, Opus 15. Mais uma vez, Dussek faz proveito das possibilidades cromáticas do pianoforte em relação à harpa e insere cromatismos na parte transcrita sempre que possível, como se tentasse quebrar a "monotonia" da escrita diatônica da harpa.

No primeiro movimento, a parte original da harpa (Figura 6) é algumas vezes substituída por outra com figurações bastante cromáticas (Figura 7), como mostrado a seguir:

Figura 6: Trecho do primeiro movimento do concerto, como escrito originalmente para harpa por Krumpholtz

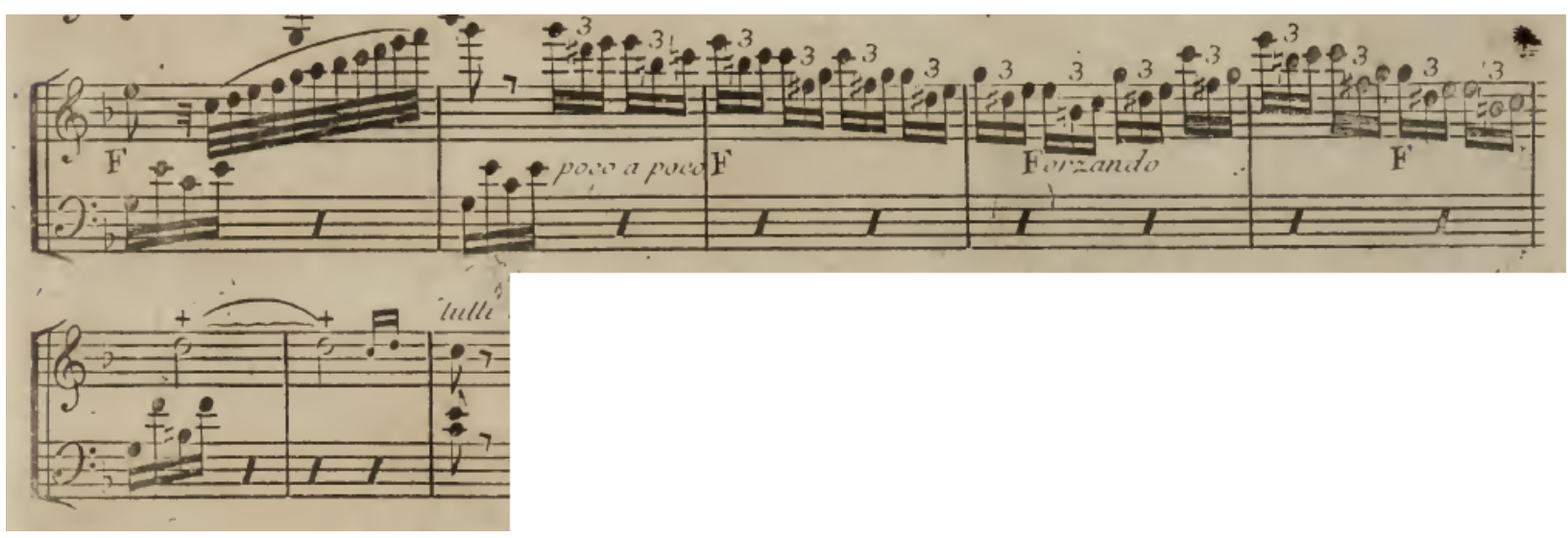

Figura 7: Transcrição para pianoforte do trecho mostrado na Figura 6 (observa-se que Dussek dobrou os valores das notas escritas, transformando em compasso quaternário o original binário de Krumpholtz. Isso, no entanto, não traz nenhuma alteração significativa à obra)

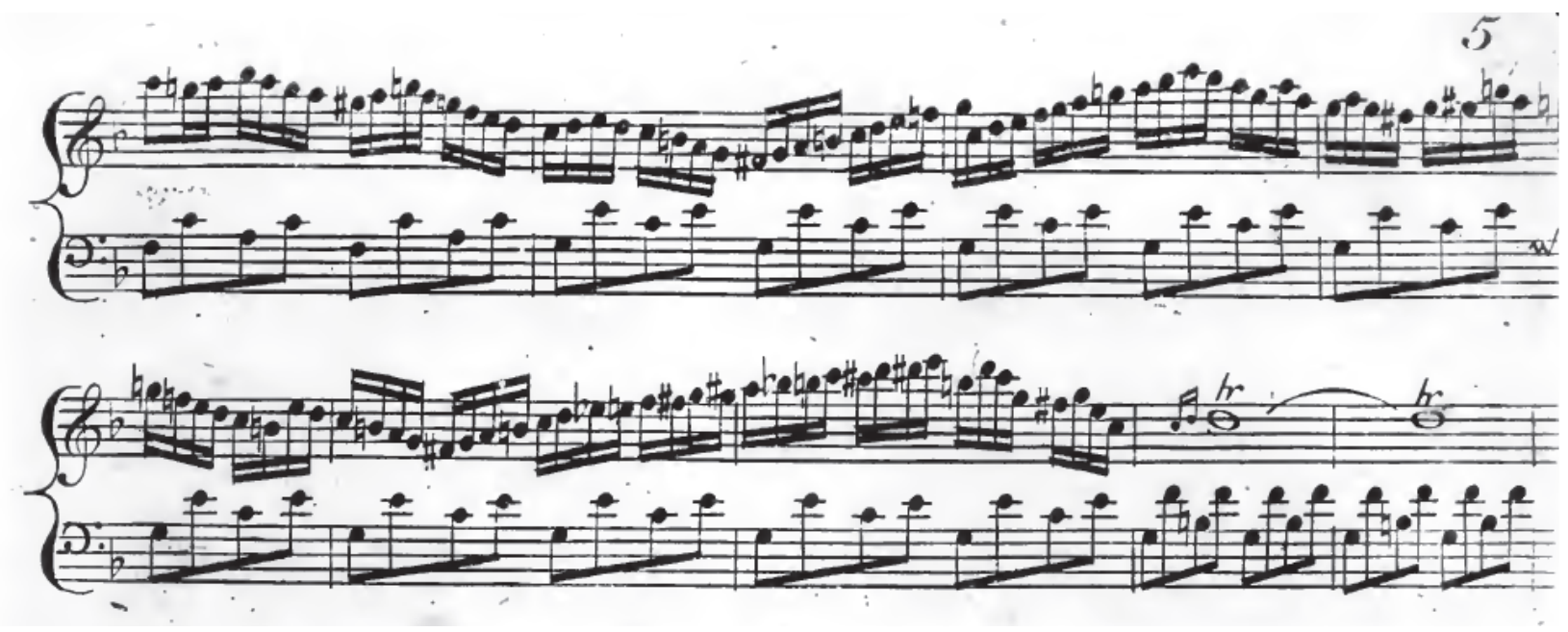

O segundo movimento do concerto é transcrito para o piano praticamente ipsis literis, quase que sem nenhuma alteração. No entanto, antes da última exposição do tema principal que culmina na pequena coda que encerra o movimento, Dussek insere uma pequena cadência também rica em cromatismos: 
Figura 8: Cadência, no segundo movimento do concerto de Krumpholtz, escrita para pianoforte por Dussek

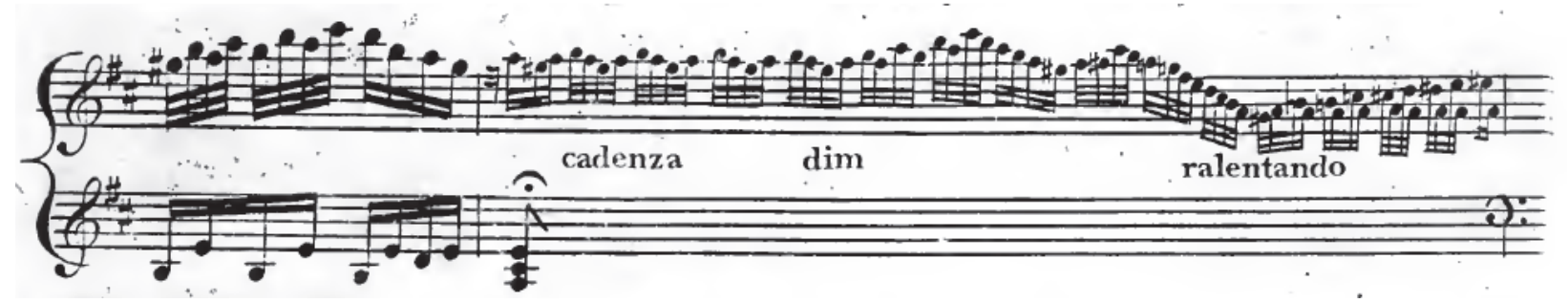

O terceiro movimento, Rondo, tem praticamente o mesmo comportamento do primeiro movimento. As diferenças de escrita privilegiam a técnica pianística e o compositor insere o seguinte trecho cromático, impossível de ser executado na harpa na velocidade do movimento:

Figura 9: Trecho cromático (os dois primeiros compassos) do terceiro movimento do concerto, escrito por Dussek na transcrição das partes de harpa de Krumpholtz

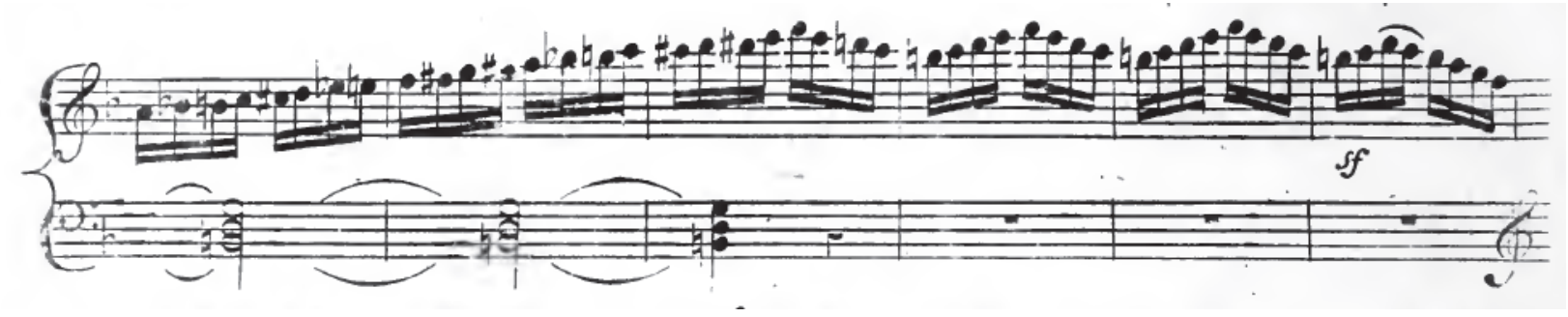

Percebe-se, portanto, que em suas transcrições Dussek mostra domínio composicional das técnicas e possibilidades tanto da harpa de pedais como do pianoforte, transformando determinadas figurações a fim de privilegiar a sonoridade e facilidade de execução dos mesmos, bem como mostrar algumas de suas características idiomáticas. Entretanto, seu grande conhecimento dos dois instrumentos fica ainda mais nítido quando o compositor combina ambos em uma mesma composição.

\section{Duos para harpa de pedais e pianoforte de dussek}

Os duos para harpa de ação-simples e pianoforte foram relativamente populares no final do século XVIII e início do XIX. Essa formação, que hoje em dia pode parecer um tanto quanto incomum, parece ter sido bem quista naquele período.

A execução desse tipo de composição torna-se problemática quando realizada em instrumentos modernos, pois a equalização das sonoridades dos dois instrumentos é muito difícil de ser obtida, o que faz com que os vários duos para harpa e pianoforte compostos sejam hoje em dia raramente ouvidos em recitais ou mesmo em gravações.

No entanto, quando tocadas nos instrumentos da época em que foram escritas, essas composições não apresentam nenhum problema de equalização sonora. Além disso, os timbres da harpa de ação-simples e do pianoforte são muito mais próximos, se comparados com os de seus parentes modernos (GRIFFITHS, 1968, p. 420).

Não é de surpreender que Dussek, a partir do seu profundo conhecimento dos dois instrumentos, tenha legado algumas das melhores peças para essa formação. O compositor abordou-a algumas vezes durante a vida e o resultado disso são os duos em Fá maior, Opus 26, em Mi bemol maior, Opus 38 e os Três Duos Concertantes, Opus 69. Esses duos são talvez as melhores peças para a análise das particularidades da escrita de Dussek para esses instrumentos, já que ali a proximidade de ambos, numa mesma composição, evidencia o trato particular dado a cada um pelo compositor. 
Segundo Ann Griffiths (1968, p. 419), os duos que formam o Opus 69 estão entre as melhores peças concebidas para harpa pelo compositor, apresentando grande interesse na escrita individual e conjunta para os instrumentos. O primeiro dos três duos (também publicado separadamente como Opus 74), em Si bemol maior, foi composto por volta de 1810 e é formado por três movimentos. Em todos eles é possível perceber que ambos os instrumentos são tratados com a mesma importância por Dussek, apresentando dificuldade técnica equivalente e mesmo grau de expressividade.

No primeiro movimento, Allegro com fuoco, as partes de harpa e de pianoforte são bastante similares. Nota-se na parte de harpa, no entanto, o predomínio de certos tipos de escalas e arpejos próprios da escrita idiomática do instrumento. A Figura 10 ilustra um trecho no qual é possível reconhecer a presença de figurações (tipos de acordes, escalas e arpejos) muito comuns no repertório da harpa no século XVIII:

Figura 10: Trecho da parte de harpa do primeiro movimento do Duo em Si bemol maior, opus 69

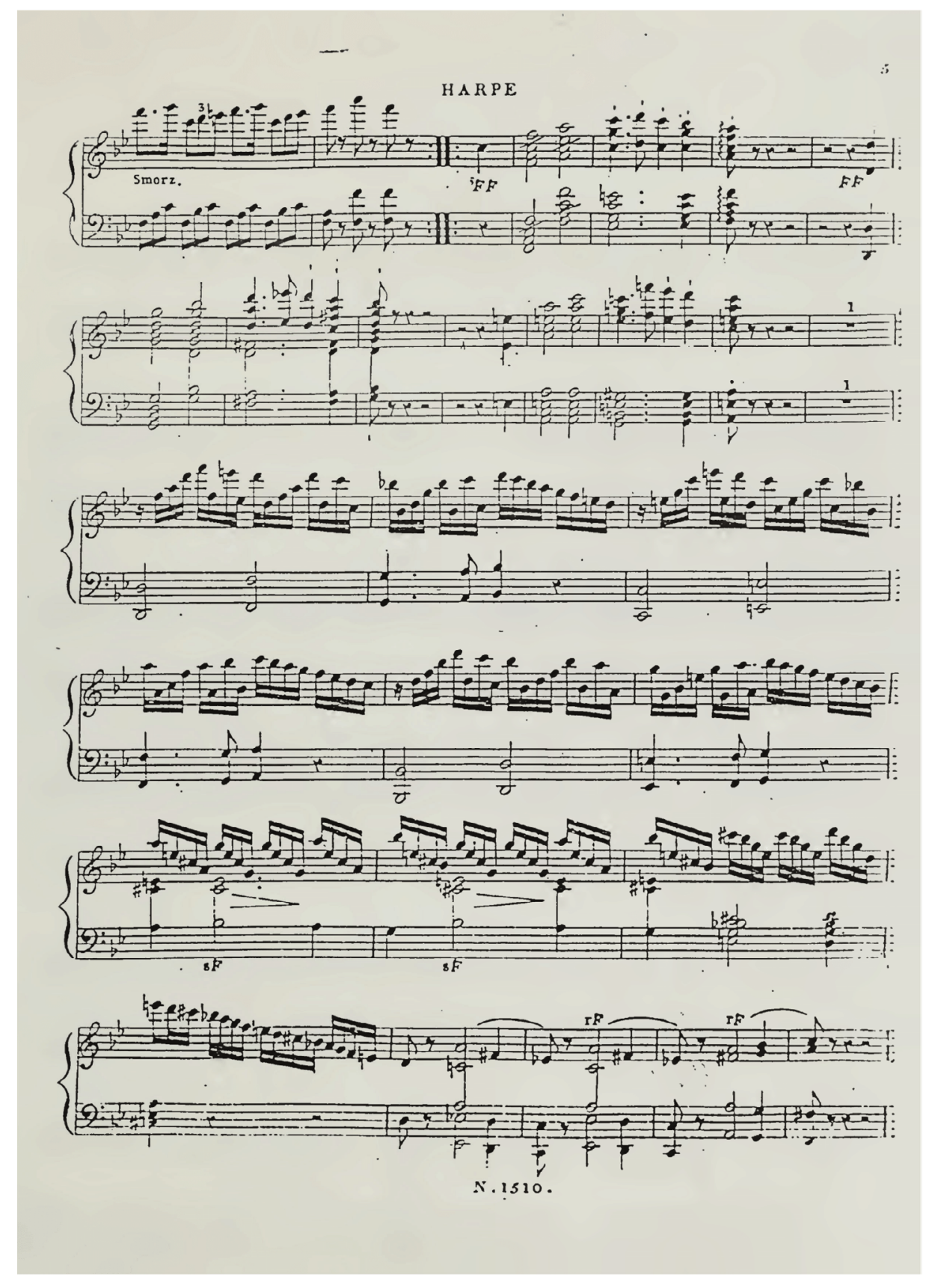


Nenhum dos instrumentos é tratado de forma demasiadamente cromática, mas notase que, naturalmente, o piano tem maior liberdade na realização desse tipo de figuração.

No segundo movimento, Andante moderato, uma marcha fúnebre, encontra-se um dos momentos mais interessantes de toda a peça, no que diz respeito à escrita idiomática de ambos os instrumentos.

Após a apresentação completa do tema principal do movimento, na tonalidade de Sol menor, Dussek inicia uma seção mais densa, em Mi bemol maior, a partir do compasso 25.

A melodia principal é entregue ao pianoforte. Sua linha é totalmente formada por acordes, tocados numa insistente figuração pontuada, ao estilo marcial, alternando registros graves e agudos, como mostra a Figura 11 (o referido trecho inicia-se após a barra dupla):

Figura 11: Trecho da parte de pianoforte do segundo movimento

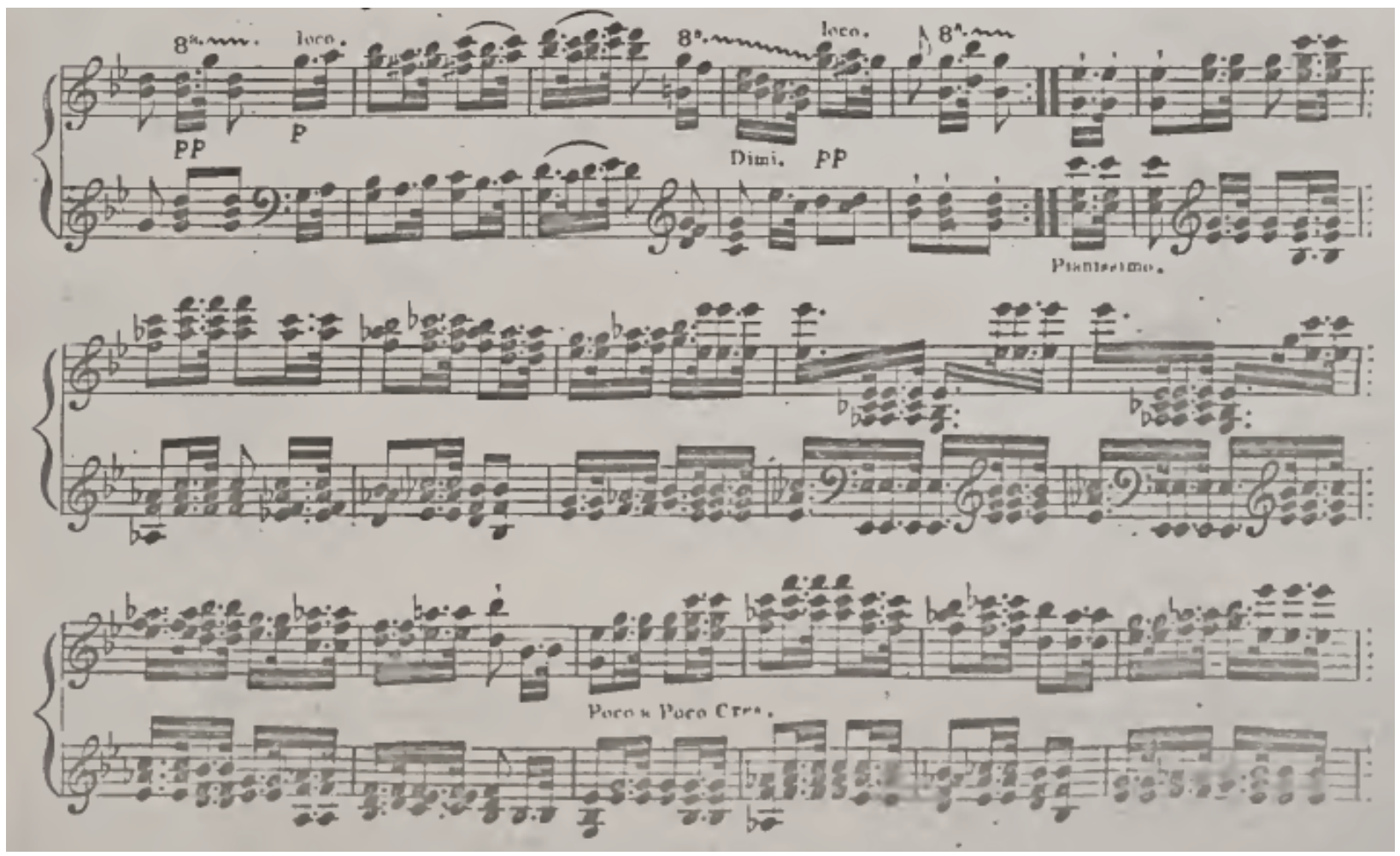

A passagem caminha de um pianíssimo inicial até um fortíssimo, alguns compassos depois. O pianoforte mostra excelente sonoridade em todo o trecho, sendo que os acordes soam claros em ambas as regiões do instrumento.

As partes de harpa nesse trecho são escritas de forma completamente diferente. Dussek com certeza sabia que as mesmas figurações que dá ao pianoforte nunca poderiam soar com a mesma qualidade e expressividade na harpa. Notas únicas ou ainda acordes repetidos muito rapidamente no instrumento param a vibração das cordas e o resultado não produz grande sonoridade, diferentemente do pianoforte, no qual a mesma figuração é perfeitamente sonora, em várias dinâmicas diferentes.

Portanto, para acompanhar a parte principal dada ao pianoforte, Dussek propõe algo distinto para a harpa. Uma vez que o primeiro permanece quase sempre na sua região mais aguda, caberia à harpa também realizar o baixo de praticamente todo o trecho. $\mathrm{O}$ compositor, necessitando assim de partes que proporcionassem à harpa uma sonoridade grandiosa que pudesse igualar-se à das partes de pianoforte do mesmo trecho, escreve o seguinte acompanhamento, ilustrado na Figura 12: 
Figura 12: Trecho da parte de harpa do segundo movimento
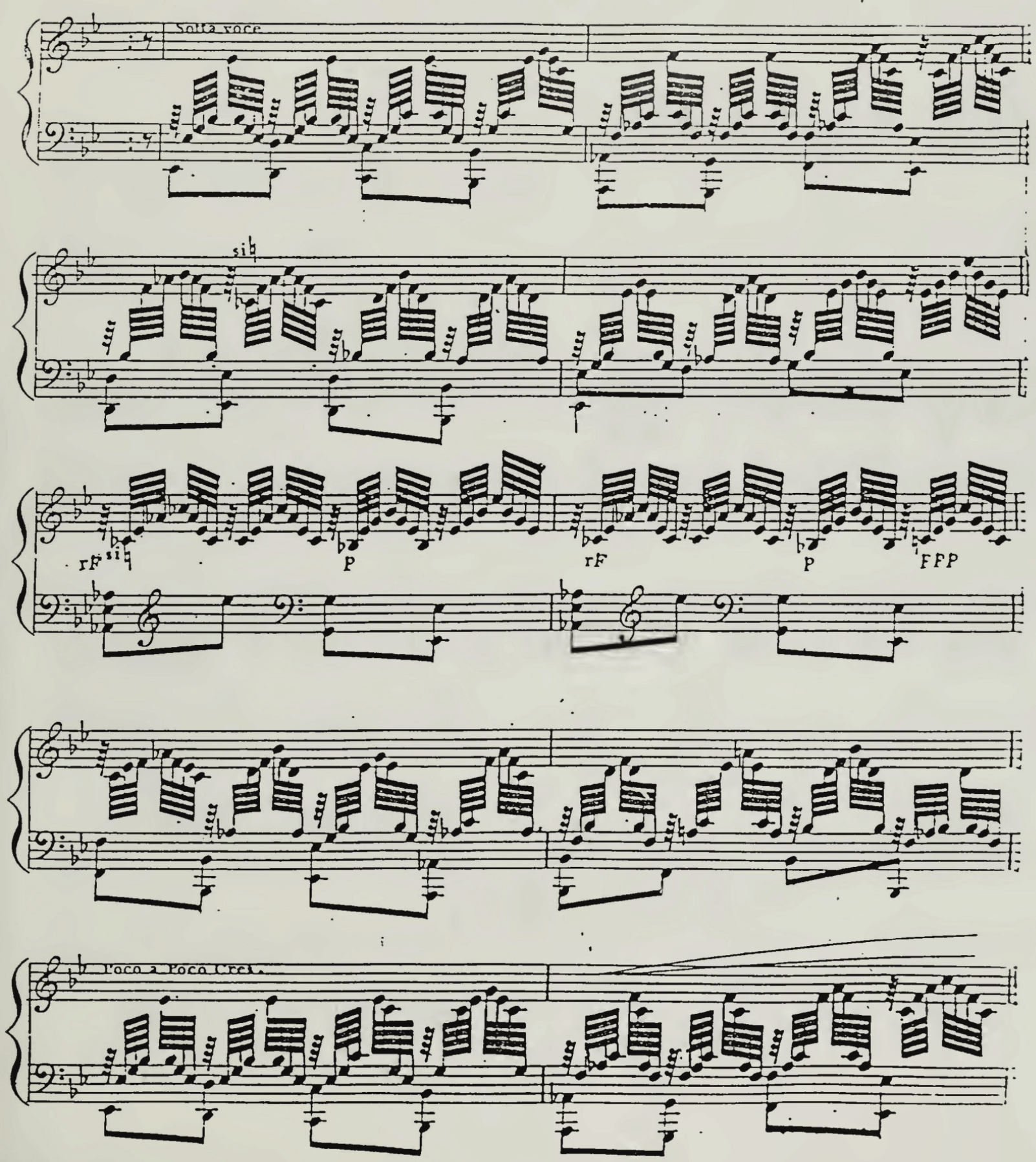

A mão esquerda realiza a linha do baixo, reforçado quase sempre por intervalos de oitava (muito sonoros na harpa) ou por acordes, que o mantém com sonoridade satisfatória durante toda a passagem. À mão direita são entregues rápidos arpejos ascendentes e descendentes, figurações também extremamente comuns no repertório do instrumento, justamente por suas qualidades idiomáticas que resultam em excelente sonoridade. Assim, o acompanhamento entregue à harpa soa de forma muito expressiva, caminhando por todas as dinâmicas exigidas pelo trecho e proporcionando sustentação à parte principal do pianoforte.

O terceiro movimento, um minueto, também apresenta escrita relativamente distinta para cada um dos instrumentos. As partes de harpa são escritas quase sempre em 
sua região mais aguda e brilhante, enquanto que o pianoforte mantém-se num registro mais grave durante praticamente todo o movimento.

As partes de pianoforte apresentam abundantes figurações em oitavas, todas ligeiras e muitas vezes na região grave do instrumento. Há, por vezes, utilização de cromatismos. A figura a seguir ilustra algumas dessas figurações:

Figura 13: Trecho da parte de pianoforte do terceiro movimento

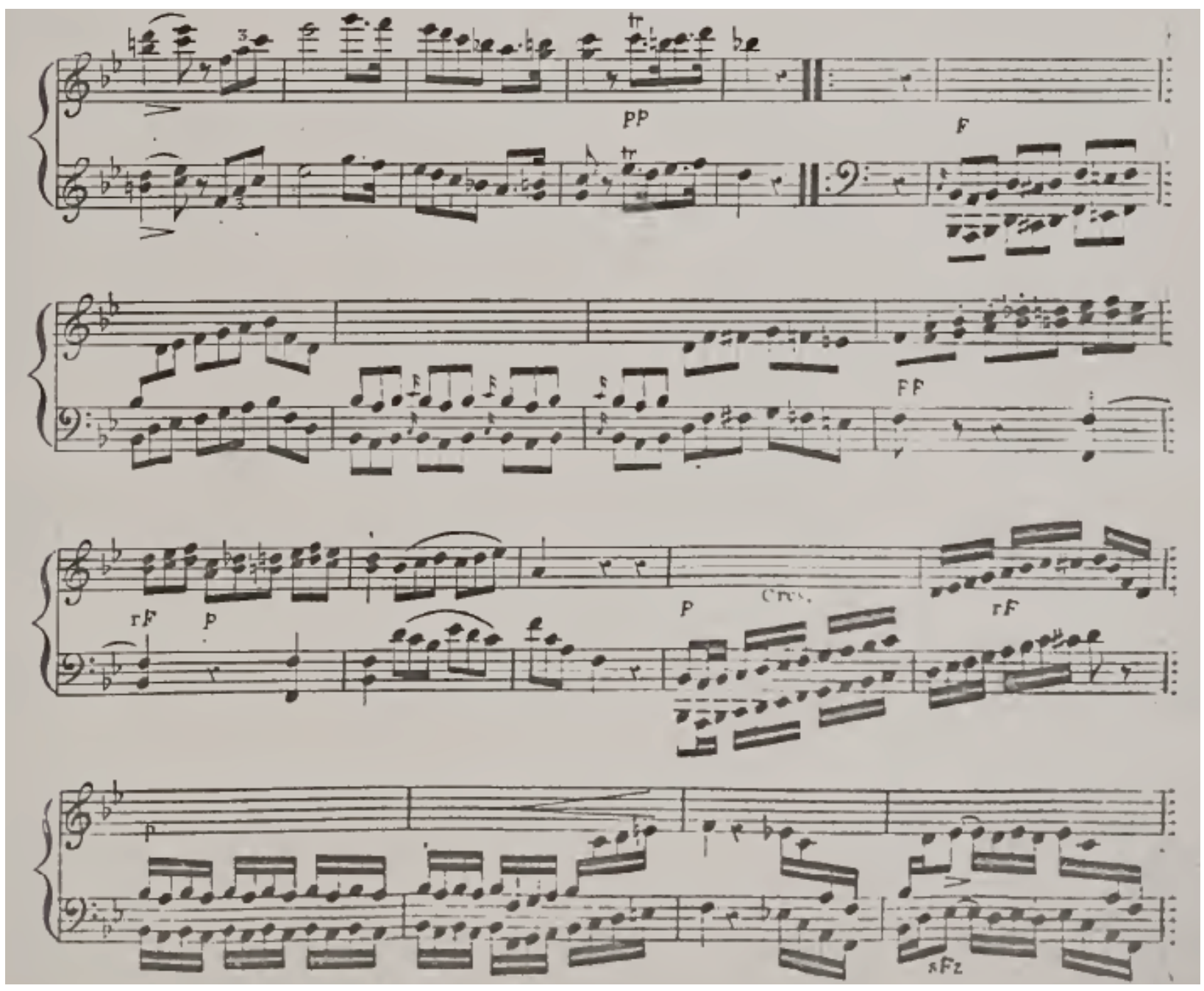

Fica claro que essas mesmas figurações nunca apresentariam bons resultados se tocadas na harpa, e Dussek entrega-as somente ao pianoforte.

Um dos momentos mais interessantes desse movimento ocorre num trecho no qual Dussek faz uso de uma harmonia mais ousada, passando por tonalidades mais distantes da inicial (Si bemol maior). Num espaço de sete compassos, o compositor passa por Si bemol e Mi bemol menor, chegando a Dó bemol maior antes de retornar à tonalidade original da peça. Conhecendo as limitações harmônicas da harpa de ação-simples, Dussek mostra sua engenhosidade entregando todo esse trecho modulatório ao pianoforte (Figura 14). A harpa toca simples notas em oitavas nos quatro primeiros compassos e depois permanece em pausa até o retorno a Si bemol maior, como mostra a Figura 15: 
Figura 14: Parte de pianoforte do terceiro movimento (o trecho modulatório citado acima encontra-se ao longo dos nove compassos após a barra dupla)

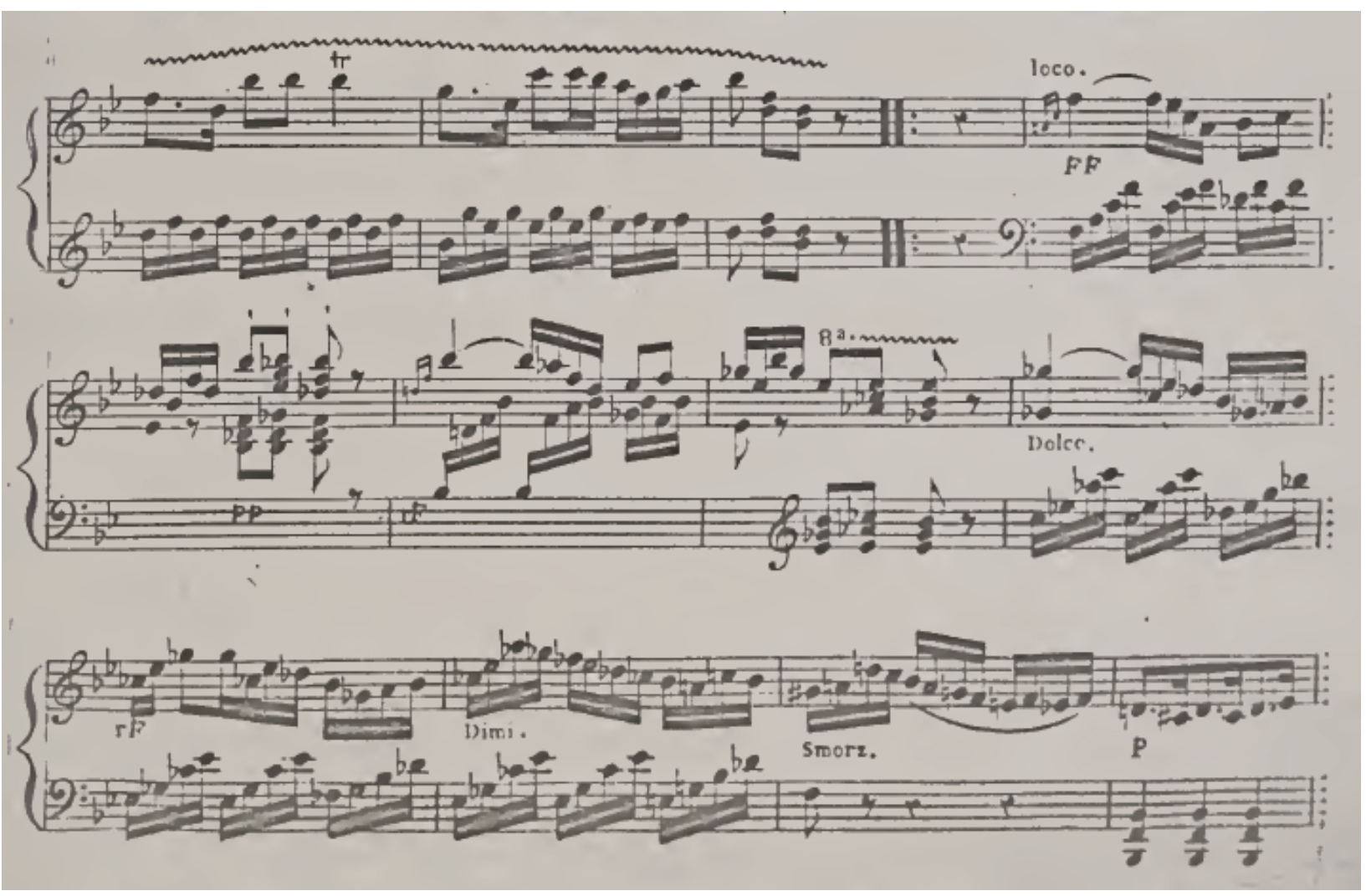

Figura 15: Parte de harpa do terceiro movimento referindo-se ao trecho modulatório que se inicia após a barra dupla

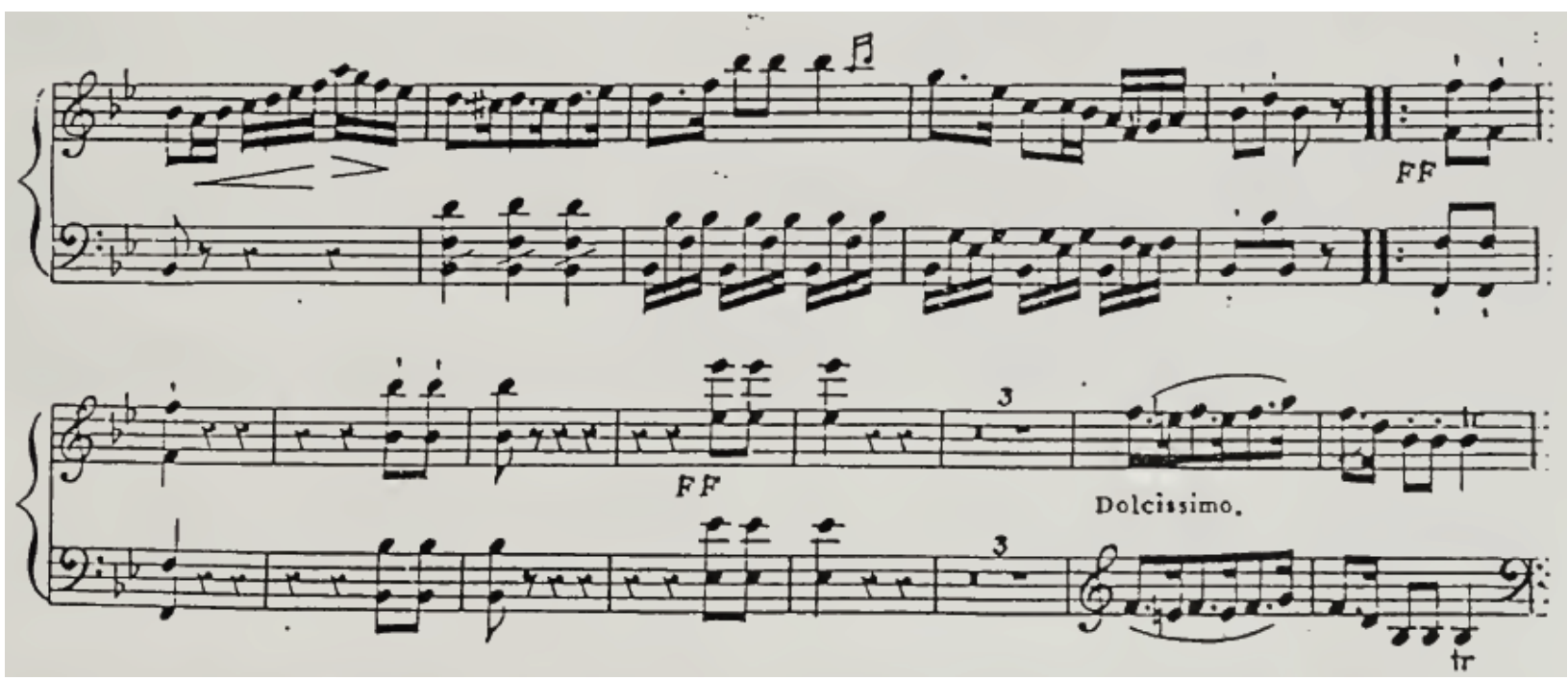

\section{Distinções estilísticas nas obras de Dussek}

Segundo Ann Griffiths (1968, p. 420), a limitação harmônica é que gera a diferença essencial entre a música para harpa e para pianoforte de Dussek, uma vez que "as modulações ousadas e as mudanças harmônicas de grande envergadura que caracterizam muito de sua música para piano são simplesmente impossíveis na harpa de ação-simples”. Isso é de fato uma realidade. Porém, mais do que impedir que a música para harpa de Dussek apresentasse harmonia audaciosa, as limitações da harpa de ação-simples parecem ter influenciado a concepção do estilo musical associado ao instrumento por parte do compositor. 
É curioso perceber que, ao escrever para harpa, Dussek parece fechar-se dentro das características de um estilo clássico mais "tradicional", enquanto que ao pianoforte o compositor mostrava-se praticamente um vanguardista. Comparando-se, por exemplo, as duas sonatas para harpa, Opus 34, com as três sonatas para pianoforte, Opus 35, que Dussek escreveu praticamente na mesma época (por volta de 1797) é possível notar grandes diferenças não só no tratamento harmônico dado pelo compositor às obras (as peças para pianoforte são, naturalmente, muito mais ricas e variadas harmonicamente), mas também no estilo das composições. As sonatas para harpa do Opus 34, intituladas Grandes Sonatas (o que sugere que as mesmas tenham sido compostas com a finalidade de serem apresentadas em concertos e não com funções didáticas), apresentam uma linguagem comum ao estilo clássico do último quarto do século XVIII, enquanto que as sonatas para piano do opus 35 ecoam o Beethoven do século XIX.

É claro que as limitações harmônicas da harpa de ação-simples podem ter contribuído para que Dussek evitasse escrever para ela num estilo mais "moderno", mas também é possível se pensar que o próprio compositor talvez encarasse o instrumento com uma visão um tanto quanto tradicionalista.

\section{Considerações finais}

Apesar de, a princípio, as escritas idiomáticas para a harpa de pedais e para o pianoforte parecerem muito similares, uma análise mais aprofundada de suas características mostra que ambas apresentam distinções significativas, diretamente responsáveis por sua organicidade e facilidade de execução e também pelo bom resultado sonoro de uma obra musical para eles composta. Portanto, o conhecimento, por parte dos compositores, da linguagem idiomática de cada um dos instrumentos é algo essencial na concepção de uma obra musical que possa ser considerada "bem escrita" para os mesmos.

Jan Ladislav Dussek destaca-se como um compositor que conhecia as características, possibilidades e limitações dos citados instrumentos, claramente aplicando esse conhecimento em suas obras. A análise de sua música para harpa de pedais e para pianoforte aqui proposta traz à tona singularidades idiomáticas dos instrumentos durante fins do século XVIII e início do XIX e a maneira distinta através da qual eram tratados pelo compositor, cuja familiaridade com a harpa e o pianoforte gerou, para ambos, uma música que dá a seus intérpretes a chance de executá-la com naturalidade técnica, ao mesmo tempo que mostra o potencial expressivo de cada instrumento, utilizando-se com habilidade dos diversos elementos musicais que melhor lhes cabiam no período. Por essas características, a obra de Dussek é importante referência no assunto, podendo ser alvo de estudo daqueles que buscam entender as singularidades da escrita idiomática não só para os aqui vistos instrumentos antigos, mas também para seus correspondentes modernos, uma vez que algumas distinções entre a linguagem harpística e pianística realizadas pelo compositor podem ser encontradas também em seus repertórios no século XIX e XX e são ainda aplicáveis em sua escrita contemporânea.

\section{Notas}

1 Tipo de escrita que valoriza as possibilidades e singularidades de um determinado instrumento musical.

2 Durante todo o século XVIII e início do XIX, as harpas de pedais eram dotadas de um mecanismo denominado de "ação-simples". O acionamento dos pedais movimentava um sistema complexo, interno ao instrumento, que repuxava suas cordas, causando um encurtamento artificial das mesmas e elevando sua altura original em meio tom. Cada pedal podia ser acionado apenas uma vez. Logo, as cordas da harpa podiam sofrer apenas uma alteração de semitom (de bemol a natural e de natural a sustenido). A harpa de pedais moderna, patenteada no início do século XIX, possui mecanismo de "ação-dupla", no qual cada pedal pode ser movimentado duas vezes, causando duas 
alterações de meio tom às cordas do instrumento. O mecanismo de ação-simples, apesar de muito engenhoso, era um limitador das capacidades harmônicas da harpa, que podia tocar em uma quantidade pequena de tonalidades e tinha suas possibilidades de modulação reduzidas.

3 Na harpa de ação-simples e também na de ação-dupla, cujas cordas são afinadas diatonicamente, os cromatismos só podem ser realizados através do acionamento dos pedais, o que torna seu uso, ainda que possível, tecnicamente trabalhoso. Os instrumentos de teclado, devido a sua natureza, podem realizar cromatismos de forma muito mais simples e natural à sua técnica de execução.

4 A citada partitura intitula-se Concerto for the Harp or Pianoforte, with the Additional Keys and Accompaniments composed by J. L. Dussek, Opus 15. A data aproximada dessa publicação é 1814, portanto, dois anos após a morte do compositor. Parte-se, aqui, do princípio de que o conteúdo dessa publicação póstuma tenha sido todo realizado por Dussek, uma vez que na edição não há indícios de que outra pessoa tenha sido responsável por ele.

5 "Krumpholtz favorite harp concerto adapted for the harpsichord or piano forte by J. L. Dussek, as performed with the utmost applause by him and Muzio Clementi”, no original.

6 Jean-Baptiste Krumpholtz, importante harpista e compositor do século XVIII.

\section{Referências}

BARTHEL, L. Au coeur de la harpe au XVIIème siècle. S.l: Garnier-François, 2005.

DUSSEK, J. L. Concerto for the harp or pianoforte with the additional keys and accompaniments, Op. 15. London: Goulding \& Co, [1814?].

DUSSEK. Deux Grandes Sonates pour Harpe avec accompagnement de violon et basse par Dusseck dediées à Madame Molinos, Oeuvre 34. Paris: Pleyel, 1797.

. Duo concertante pour harpe et pianoforte, Op. 74. Paris: Naderman, 1810.

. Krumpholtz favorite harp concerto adapted for the harpsichord or piano forte. London: Longman \& Broderip, 1790.

. Trois Grandes Sonates pour Piano-Forte dediées a Gabrielle Pleyel par J. L. Dusseck, Oeuvre 35. Paris: Pleyel, [ca.1797].

CRAW, H. A. Dussek. In: . The New Grove Dictionary of Music and Musicians. 2. ed. New York: Oxford University Press, 2001. p. 761-765, vol. 7.

ÉRARD, P. The harp in its present improved state compared with the original pedal harp. London: [s.n], 1821.

FÉTIS, F. Notice biographique sur Sébastien Érard, chevalier de la Légion-D’Honneur. Paris: E. Duverger, 1831.

GRANGIER, A. A genius of France - a short sketch of the famous inventor Sebastien Erard and the firm he founded in Paris, 1780. 3. ed. Paris: Maison Erard, 1924.

GRIFFITHS, A. Dussek and the Harp. The Musical Times, [S.1], v. 109, n. 1503, p. 419-420, 1968.

KRUMPHOLTZ, J-B. Sixieme Concerto pour la harpe, Oeuvre IX. Paris: Viguerie, 1785.

PARKER, M. Child of Pure Harmony - A source book for the single-action harp. [London]: [s.n], 2005. E-book.

COLE, M. Pianoforte. In: . The New Grove Dictionary Of Music And Musicians. 2. ed. New York: Oxford University Press, 2001. p. 663-667. v. 19.

RENSCH, R. Harps and harpists - revised edition. 2. ed. Bloomington: Indiana University Press, 2017.

VERNILLAT, F. La littérature de la harpe en France au XVIIIe siècle. "Recherches" sur la Musique françaises classique, Paris, n. 9, p. 162-185, 1969. 
Felipe Faglioni é graduado em Composição e Regência pelo Instituto de Artes da UNESP, foi de 2009 a 2018 regente assistente da Orquestra Acadêmica da mesma universidade. Natural de Rio Claro, no interior de São Paulo, iniciou seus estudos de violino na cidade, vindo mais tarde a integrar a orquestra sinfônica local. De 2012 a 2015 ocupou, na Orquestra Sinfônica de Rio Claro, o cargo de diretor artístico e regente titular. Dedica-se ao estudo da harpa sinfônica e da flauta transversal barroca (traverso), fazendo parte do Núcleo de Música Antiga da EMESP (Escola de Música do Estado de São Paulo). É mestre em musicologia pelo programa de pós-graduação da UNESP, e doutorando pela Escola de Comunicações e Artes da USP 